\title{
A catalase from Streptomyces coelicolor A3(2)
}

\author{
G. E. Walker, ${ }^{1}$ Bryan Dunbar, ${ }^{3}$ lain S. Hunter, ${ }^{2}$ Hugh G. Nimmo' \\ and John R. Coggins ${ }^{1}$
}

Author for correspondence: John R. Coggins. Tel: +44141330 5267. Fax: +441413304620.

e-mail: gbca06@udcf.gla.ac.uk

\section{1,2 Departments of Biochemistry ${ }^{1}$ and Genetics2, University of Glasgow, Glasgow G12 8QQ, UK \\ 3 Department of Molecular and Cell Biology, University of Aberdeen, Aberdeen AB9 1AS, UK}

\begin{abstract}
Catalase was purified from the Gram-positive bacterium Streptomyces coelicolor A3(2) in a three-step purification procedure comprising $\left(\mathrm{NH}_{4}\right)_{2} \mathrm{SO}_{4}$ fractionation, Phenyl-Sepharose chromatography and Mono $Q$ chromatography. The purification of catalase, as judged by the final specific activity of $110000 \mathrm{U} \mathrm{mg}^{-1}$, was 250 -fold with a $35 \%$ yield. The native protein was a homotetramer with a subunit $M_{r} 55000$. $N$-terminal and internal peptide sequence analyses showed that there was a high degree of sequence similarity between the $S$. coelicolor catalase and other microbial and mammalian catalases. Southern blot analysis indicated that there was a single catalase gene in S. coelicolor. The specific activity of catalase throughout the growth of batch cultures was investigated and elevated catalase activity was found in stationary-phase cells.
\end{abstract}

Keywords: catalase, Streptomyces coelicolor

\section{INTRODUCTION}

Oxidative stress occurs when the concentration of active oxygen species in a cell is greater than the scavenging defence of the cell and damage to DNA, RNA, protein and lipids can occur. Consequently, virtually all aerobic organisms have evolved complex inducible deterrence and repair mechanisms to alleviate the damaging effects of active oxygen (McCord et al., 1971; McCord \& Fridovich, 1988).

One anti-oxidant mechanism, namely the scavenging of $\mathrm{H}_{2} \mathrm{O}_{2}$, is mediated by the activity of peroxidases and catalases. The most common form of catalase in both prokaryotes and eukaryotes is a haem protein which is active as a tetramer of subunits of $60000 M_{\mathrm{r}}$, with a maximum of one protohaem IX group bound per subunit (Deisseroth \& Dounce, 1970). Other divergent forms of differing subunit size, structure and prosthetic group have been identified in different bacteria, e.g. Escherichia coli (Loewen \& Switala, 1986; Claiborne et al., 1979) and Bacillus subtilis (Loewen \& Switala, 1987, 1988). Many bacteria also possess a bifunctional catalase-peroxidase, with properties distinct from the classical catalases and peroxidases described from higher organisms. In E. coli this activity resides in a tetramer of subunit $M_{\mathrm{r}} 78000$ (Claiborne \& Fridovich, 1979). The sequence of this

Abbreviations: FPLC, fast protein liquid chromatography; PVDF, polyvinylidene difluoride.

The PIR accession number for the peptide sequence reported in this paper is A44639. protein bears no resemblance to other catalases (TriggsRaine et al., 1988); instead it appears more related to the peroxidases of Bacillus stearothermopbilus (Loprasert et al., 1989) and Mycobacterium tuberculosis (Zhang et al., 1992).

In many organisms catalase activity increases in response to oxidative stress (Jacob \& Orme-Johnson, 1977; Christman et al., 1985; Loewen et al., 1985; Chary \& Natvig, 1989; Lee et al., 1993). In E. coli the bifunctional catalase-peroxidase, $\mathrm{KatG}$, is inducible by $\mathrm{H}_{2} \mathrm{O}_{2}$ (Loewen et al., 1985). Furthermore, catalase activity is also modulated by internal developmental events (Loewen \& Switala, 1988; Chary \& Natvig, 1989), and in a growthphase-dependent manner as described for the $E$. coli monofunctional catalase, KatE (Schellhorn \& Hassan, 1988).

The genus Streptomyces comprises a group of Grampositive obligately aerobic bacteria. They exhibit a sedentary mycelial growth habit, followed by morphological differentiation to form spores which are dispersed to colonize new environments. This developmental stage is preceded by nutrient depletion, and often coincides with antibiotic production (Chater, 1984). Thus, antibiotic production can be thought of as a form of stress response (Demain, 1989). Streptomyces coelicolor A3(2) is a genetically well-characterized strain which provides a suitable vehicle for the study of stress responses, growth, antibiotic production and their possible relationships.

Little is known about the oxidative defences of $S$. coelicolor, although recent evidence has indicated that a coordinated response to oxidants does occur (Lee et al., 1993). To 
elucidate one component of the oxidative defence mechanism, a study of catalase was undertaken in S. coelicolor. This paper describes the purification of a single, soluble catalase from $S$. coelicolor at different stages of the growth cycle, and reports the $\mathrm{N}$-terminal and internal amino acid sequences of this single catalase. After this work was completed a paper describing the characterization of the major catalase from $S$. coelicolor ATCC 10147 was published (Kim et al., 1994).

\section{METHODS}

Reagents. Phenyl-Sepharose CL-4B was supplied by Pharmacia. Pre-packed Mono Q, and Superose 12 columns were obtained from Pharmacia and utilized on a Pharmacia fast protein liquid chromatography (FPLC) system. Junlon PW110 was a gift from Honeywell and Stein, Wellington, UK. Polyvinylidene diffuoride (PVDF) membrane (Problott) was obtained from Applied Biosystems. $\left[\gamma^{32}\right]$ ATP and Hybond-N nylon filters were obtained from Amersham.

Bacterial strains and growth conditions. S. coelicolor JI3456 $\left(\mathrm{SCP} 1^{\mathrm{NF}}, \mathrm{SCP}^{-}\right)$was provided by Professor D. A. Hopwood, John Innes Institute, Norwich, UK. Cultures were grown at $30{ }^{\circ} \mathrm{C}$ on an orbital shaker at 200 r.p.m either in 11 conical flasks containing $200 \mathrm{ml}$ medum or in $2 \mathrm{l}$ flasks containing $400 \mathrm{ml}$ medium. The minimal medium comprised inorganic salts supplemented with $0.4 \%(\mathrm{w} / \mathrm{v})$ glucose as sole carbon and energy source (Hobbs et al., 1989). For enzyme purification from exponential-phase cells, a $200 \mathrm{ml}$ starter culture was inoculated with spores washed from one fresh soya-mannitol slope and grown for $18 \mathrm{~h}$. This culture was then used to inoculate $9 \times 400 \mathrm{ml}$ cultures $(20 \mathrm{ml}$ inoculum per $400 \mathrm{ml}$ ), which were grown for a further $24 \mathrm{~h}$ (total growth time of $42 \mathrm{~h}$ ) and harvested when growing exponentially. Growth experiments were carried out using the same procedure for the starter culture, then individual 21 flasks were harvested at appropriate time points. For enzyme purification from stationary-phase cells, a $200 \mathrm{ml}$ starter culture was inoculated with spores washed from one fresh soya-mannitol slope and grown for $40 \mathrm{~h}$. This culture was then used to inoculate $6 \times 400 \mathrm{ml}$ cultures $(30 \mathrm{ml}$ inoculum per $400 \mathrm{ml}$ ), which were grown for a further $22 \mathrm{~h}$ (total growth time of $62 \mathrm{~h}$ ) and harvested when in stationary phase.

Catalase assay. Catalase was assayed by following the disappearance of peroxide spectrophotometrically at $240 \mathrm{~nm}$ as described by Beers \& Sizer (1952). The assay cocktail contained $50 \mathrm{mM}$ Bistrispropane/ $\mathrm{HCl} \mathrm{pH} \mathrm{7.0,18} \mathrm{mM} \mathrm{H}_{2} \mathrm{O}_{2}$ in a final volume of $1 \mathrm{ml}$. Assays were carried out at $25^{\circ} \mathrm{C}$ with one unit of enzyme activity defined as the amount catalysing the conversion of $1 \mu \mathrm{mol}$ substrate into product $\mathrm{min}^{-1}$.

Protein estimation. Protein was determined by the method of Bradford (1976) or by a variation of the Lowry method with BSA as standard.

Purification of catalase from exponential-phase cells. Unless otherwise stated, all manipulations following cell breakage were done at $4{ }^{\circ} \mathrm{C}$.

Step 1: Extraction and centrifugation. A $135 \mathrm{~g}$ (wet weight) batch of exponential-phase cells of $S$. coelicolor was suspended in $20 \mathrm{ml}$ extraction buffer (100 mM Bistrispropane/ $\mathrm{HCl} \mathrm{pH} 7 \cdot 5)$ and broken by two passages through a French pressure cell (950 p.s.i.; $6.55 \mathrm{MPa}$ ). This material was then centrifuged at $100000 \mathrm{~g}$ for $1 \mathrm{~h}$. Catalase was purified from the resulting cellfree extract.

Step 2: Salt fractionation with $\left(\mathrm{NH}_{4}\right)_{2} \mathrm{SO}_{4}$. Solid $\left(\mathrm{NH}_{4}\right)_{2} \mathrm{SO}_{4}$ was added to give $35 \%$ saturation $\left(209 \mathrm{~g} \mathrm{l}^{-1}\right)$. The mixture was stirred for $20 \mathrm{~min}$ and the precipitated proteins were removed by centrifugation at $28000 \mathrm{~g}$ for $20 \mathrm{~min}$. The supernatant was adjusted to $65 \%$ saturation with solid $\left(\mathrm{NH}_{4}\right)_{2} \mathrm{SO}_{4}\left(199 \mathrm{~g} \mathrm{l}^{-1}\right)$ and stirred for $20 \mathrm{~min}$. The precipitated protein was collected by centrifugation at $28000 \mathrm{~g}$ for $20 \mathrm{~min}$ and redissolved in $10 \mathrm{ml}$ $50 \mathrm{mM}$ Bistrispropane/ $\mathrm{HCl}$ pH 7.5, 0.9 $\mathrm{M}\left(\mathrm{NH}_{4}\right)_{2} \mathrm{SO}_{4}$ (buffer A).

Step 3: Hydrophobic-interaction chromatography on PhenylSepharose. The redissolved protein from step 2 was loaded onto a Phenyl-Sepharose hydrophobic interaction column (bed volume $10 \mathrm{ml}$ ) equilibrated in buffer $A$. The column was washed with buffer $\mathrm{A}$ until the $A_{\mathbf{2 8 0}}$ of the eluate was less than $0 \cdot 1$. Protein was eluted from the column with a $200 \mathrm{ml}$ gradient of

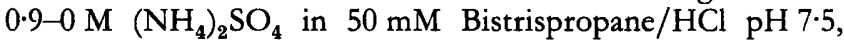
collecting $5 \mathrm{ml}$ fractions. These were assayed for catalase activity and those containing the highest activity were retained.

Step 4: Anion-exchange chromatography on Mono Q. The previously retained fractions were concentrated and dialysed against $500 \mathrm{ml} 20 \mathrm{mM}$ Bistrispropane $/ \mathrm{HCl} \mathrm{pH} 7.5$ (buffer B). The procedure was then carried out at room temperature using a Pharmacia FPLC system. The dialysate was applied to an analytical Mono $Q$ anion-exchange column (volume $1 \mathrm{ml}$ ) equilibrated in buffer B. Following washing with buffer B, protein was eluted with a gradient of $200-400 \mathrm{mM} \mathrm{NaCl}$ in $25 \mathrm{ml}$ buffer B. Fractions $(0.5 \mathrm{ml})$ were collected and assayed as before.

Purification of catalase from stationary-phase cells. Unless otherwise stated all manipulations following cell breakage were done at $4{ }^{\circ} \mathrm{C}$. Steps 1 and 2 were carried out as described above.

Step 3: Anion-exchange chromatography on Mono Q. The precipitated protein was redissolved in $5 \mathrm{ml} 50 \mathrm{mM}$ potassium phosphate $\mathrm{pH} 7 \cdot 0$ (buffer $\mathrm{C}$ ) and dialysed overnight against buffer $\mathrm{C}$. The next two procedures were carried out at room temperature using a Pharmacia FPLC system. The dialysate was applied to an analytical Mono $Q$ anion-exchange column (volume $1 \mathrm{ml}$ ) equilibrated in buffer $\mathrm{C}$. Following washing with buffer $\mathrm{C}$, protein was eluted with a gradient of $\mathrm{Na}_{2} \mathrm{SO}_{4}$ in buffer C. Fractions $(0.5 \mathrm{ml})$ were collected and assayed as before.

Step 4: Anion-exchange chromatography on Mono Q. The previously retained fractions were dialysed against $500 \mathrm{ml}$ buffer B. The dialysate was then applied to an analytical Mono $Q$ anion-exchange column (volume $1 \mathrm{ml}$ ) equilibrated in buffer $\mathrm{B}$. Following washing with buffer $\mathrm{B}$, protein was eluted with a gradient of $200-400 \mathrm{mM} \mathrm{NaCl}$ in $25 \mathrm{ml}$ buffer B. Fractions $(0.5 \mathrm{ml})$ were collected and assayed as before.

SDSPAGE. This was performed by the method of Laemmli (1970), with a $3 \%(\mathrm{w} / \mathrm{v})$ stacking gel and a $10 \%(\mathrm{w} / \mathrm{v})$ running gel. After electrophoresis, gels were stained for protein using Coomassie Brilliant Blue.

Determination of native $\boldsymbol{M}_{\mathbf{r}}$. The native $M_{\mathrm{r}}$ of the purified protein was estimated by gel permeation chromatography on a Superose 12 column mounted on a Pharmacia FPLC system. Standard proteins of known $M_{\mathrm{r}}$ were used to calibrate the column: E. coli shikimate dehydrogenase $\left(M_{\mathrm{r}} 30000\right)$, pig heart malate dehydrogenase $\left(M_{\mathrm{r}} 70000\right)$, pig muscle lactate dehydrogenase $\left(M_{\mathrm{r}} 140000\right)$, rabbit muscle aldolase $\left(M_{\mathrm{r}} 160000\right)$, bovine catalase $\left(M_{\mathrm{r}} 232000\right)$ and horse apoferritin $\left(M_{\mathrm{r}} 440000\right)$. A standard curve of peak elution volume $\left(V_{\mathrm{e}}\right)$ against $M_{\mathrm{r}}$ was constructed. The column was washed with $50 \mathrm{mM}$ potassium phosphate $\mathrm{pH} 7 \cdot 0,150 \mathrm{mM} \mathrm{NaCl}$ at a flow rate of $0.2 \mathrm{ml} \mathrm{min}^{-1}$ and $0.1 \mathrm{ml}$ fractions were collected and assayed appropriately.

Protein and peptide microsequencing. Essentially homogeneous samples of catalase were subjected to SDS-PAGE in a $10 \%(\mathrm{w} / \mathrm{v})$ gel and electroblotted onto PVDF membrane for $\mathrm{N}$ terminal sequence analysis. Samples were also loaded onto an 
$18 \%(\mathrm{w} / \mathrm{v})$ SDS gel and the protein was partially digested with V8 proteinase during electrophoresis (Cleveland et al., 1977), and electroblotted. Intact protein and peptide fragments were microsequenced (Matsudaira, 1987) using an Applied Biosystems $477 \mathrm{~A}$ protein sequencer. Further samples were digested to completion with clostripain. The resulting peptides were purified by reversed-phase HPLC and sequenced using a Milligen 6600 Prosequencer.

Protein sequence analysis. The obtained protein and peptide sequences were compared to the sequence data bases by using either the BLAST algorithm (Altschul et al., 1990) or the sequence analysis programs of the University of Wisconsin Genetics Computer Group (Devereux et al., 1984).

Design and synthesis of oligonucleotide probes. From the primary sequence data of catalase, degenerate oligonucleotides were designed as gene probes. An oligonucleotide (32mer, five degeneracies) was designed corresponding to the N-terminal sequence of residues 2-12 of catalase using the known streptomycete codon usage (Wright \& Bibb, 1992). Similarly, the sequence of residues 2-10 of the clostripain-derived peptide was used and an oligonucleotide constructed (24mer, four degeneracies). These oligonucleotides were synthesized by $\mathrm{Dr}$ V. Math, Department of Biochemistry, University of Glasgow, with an Applied Biosystems model 380A DNA synthesizer.

Molecular biological methods. Total DNA of $S$. coelicolor was prepared essentially as described by Hopwood et al. (1985). Other molecular procedures were carried out as described by Sambrook et al. (1989). Genomic DNA digests were transferred to Hybond-N as described by Southern (1975). Radiolabelled oligonucleotide was prepared by incubating $\left[\gamma_{-}^{32}\right]$ ATP and oligonucleotide with T4 polynucleotide kinase. Filters were incubated with radiolabelled oligonucleotide as described by Binnie (1990).

Filters for hybridization experiments were prepared as follows: aliquots $(5 \mu \mathrm{g})$ of $S$. coelicolor genomic DNA were digested with a range of restriction enzymes, the products were separated by electrophoresis through a $0.8 \%(\mathrm{w} / \mathrm{v})$ agarose gel and transferred to a nylon filter. Hybridization with the N-terminal oligonucleotide was carried out with the following conditions: the filter was incubated with probe for $90 \mathrm{~min}$ in $6 \times \mathrm{SSC}$ ( $1 \times \mathrm{SSC}$ is $0.15 \mathrm{M} \mathrm{NaCl}$ plus $0.015 \mathrm{M}$ sodium citrate), $0.5 \%$ (w/v) sodium pyrophosphate and $0.5 \%(\mathrm{w} / \mathrm{v})$ SDS at $60^{\circ} \mathrm{C}$. Washing was done at $65^{\circ} \mathrm{C}$ in $1 \times \mathrm{SSC}, 0.05 \% \mathrm{SDS}$. The filter was then stripped and re-probed with the internal oligonucleotide under identical conditions of salt and temperature.

\section{RESULTS AND DISCUSSION}

\section{Purification of catalase}

A single catalase has been isolated from exponential- and stationary-phase cells of $S$. coelicolor. The enzyme was prepared from exponential-phase cells as described in

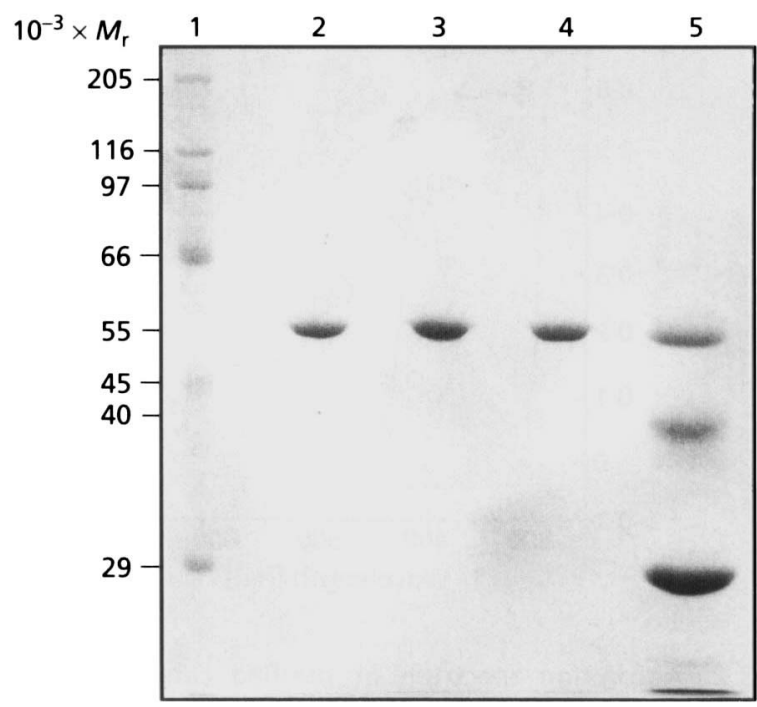

Fig. 1. SDS-PAGE of catalase fractions eluted from Mono Q. Lanes: 1 and $5, M_{r}$ markers; $2,5 \mu \mathrm{g}$ catalase; $3,8 \mu \mathrm{g}$ catalase; 4, $5 \mu \mathrm{g}$ catalase. The gel was stained with Coomassie Brilliant Blue.

Methods. The purification of catalase as judged by the final specific activity of $110000 \mathrm{U} \mathrm{mg}^{-1}$ was 250 -fold with a $35 \%$ yield (Table 1 ). Catalase was estimated to constitute more than $95 \%$ of the protein of the most highly purified preparations (Fig. 1).

The absorption spectrum of the purified $S$. coelicolor catalase is shown (Fig. 2). The absorption maximum at $406 \mathrm{~nm}$ is characteristic of the protohaem IX group found in mammalian and other monfunctional catalases (Deisseroth \& Dounce, 1970; Kim et al., 1994). The $A_{406} / A_{280}$ ratio of 0.82 is comparable with that observed for other purified bacterial catalases and demonstrates that the haem groups have not been lost during purification (Jones et al., 1970; Jouve et al., 1983; Kim et al., 1994).

At no stage in our purification procedures did we resolve more than one catalase activity, and we concluded that a single catalase was present in S. coelicolor. Evidence for a single catalase gene in Haemophilus influenzae was reported recently (Bishai et al., 1994), the sequence of which bears striking similarity to the amino acid sequences obtained from the purified $S$. coelicolor catalase (Fig. 3).

Table 1. Purification of $S$. coelicolor catalase from exponential-phase cells

\begin{tabular}{|lccccc|}
\hline Step & $\begin{array}{c}\text { Total } \\
\text { protein } \\
(\mathbf{m g})\end{array}$ & $\begin{array}{c}\text { Total } \\
\text { activity } \\
\text { (U) }\end{array}$ & $\begin{array}{c}\text { Specific } \\
\text { activity } \\
\left(\mathbf{U ~ m g}^{-1}\right)\end{array}$ & $\begin{array}{c}\text { Yield } \\
\text { (\%) }\end{array}$ & $\begin{array}{c}\text { Purification } \\
\text { (-fold) }\end{array}$ \\
\hline 1. Crude & 430 & 190000 & 440 & 100 & 1 \\
2. $\left(\mathrm{NH}_{\mathbf{4}}\right)_{\mathbf{2}} \mathrm{SO}_{\mathbf{4}}$ & 146 & 104000 & 710 & 54 & $1 \cdot 6$ \\
3. Phenyl-Sepharose & $6 \cdot 36$ & 80000 & 12600 & 42 & 29 \\
4. Mono Q & $0 \cdot 6$ & 66000 & 110000 & 35 & 250 \\
\hline
\end{tabular}




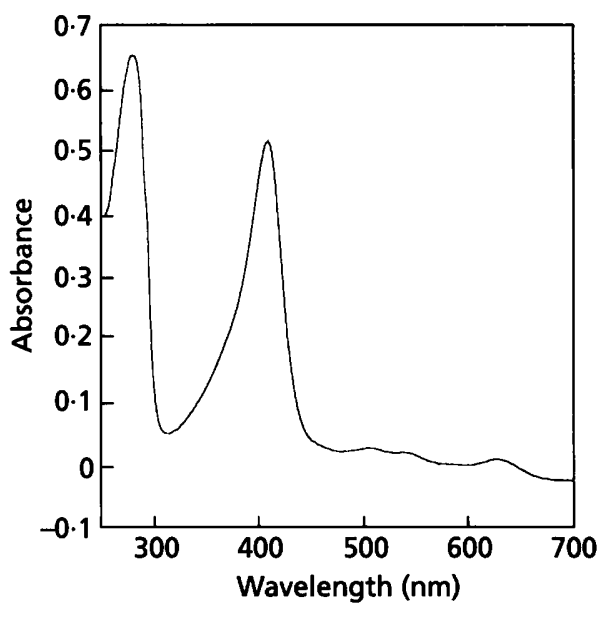

Fig. 2. Absorption spectrum of purified catalase. A $0.5 \mathrm{ml}$ fraction of the most highly purified material was made to a final volume of $1 \mathrm{ml}$ with distilled $\mathrm{H}_{2} \mathrm{O}$. The spectrum was recorded versus a blank of $20 \mathrm{mM}$ Bistrispropane buffer (pH 7.5).

\section{Quaternary structure}

The subunit $M_{\mathrm{r}}$ of the purified enzyme, determined under denaturing conditions by comparing electrophoretic mobility with the mobility of standard proteins of known $M_{\mathbf{r}}$ (Fig. 1), was $55000 \pm 2000$. Partially purified material was used for the gel-permeation chromatography. A single peak of catalase activity was eluted and the measured peak $V_{\mathrm{e}}$ corresponded to a native $M_{\mathrm{r}}$ of $195000 \pm 15000$.

These data indicate that the enzyme is tetrameric and in this respect resembles the mammalian catalases (e.g. Deisseroth \& Dounce, 1970), and differs from the dimeric catalase found in E. coli (Loewen \& Switala, 1986; Claiborne et al., 1979).

\section{Microsequencing and comparison of amino acid sequences among several catalases}

The sequence of the first 26 amino acid residues of the $\mathrm{N}$ terminus was determined (Fig. 3). Peptides for sequencing were also generated by in situ proteolysis with V8 proteinase. These were transferred onto PVDF membrane and 65 amino acids were sequenced from three peptides. Peptides 2 and 3 overlapped by seven amino acids (bold lettering in Fig. 3). A further sample was subjected to proteolysis by clostripain, and the resulting peptides were purified by reversed-phase HPLC, and one peptide yielded 13 amino acids of sequence (peptide 4, Fig. 3).

A high degree of similarity between the $S$. coelicolor amino acid sequences and other microbial and mammalian catalases was observed (Fig. 3). The $\mathrm{N}$-terminal amino acid sequence of $S$. coelicolor catalase showed the greatest similarity to other prokaryotic catalases (Fig. 3), including the bromoperoxidase-catalase of Streptomyces venezuelae. This organism, unlike $S$. coelicolor, produces the chlorinated antibiotic chloramphenicol. The bromo-
1 PENNQKPLTTVAGAPVPDNQNSLTSG 26 Sco N-terminus

1 VT.G...E.........E.A. 24 Sve (718)

1 MSSNK...SW....G........ 24 Bsu (588)

8 SHLAATN. MGN............ 33 Hin (588)

1 MTDRRN...NQ.V.IG.....M.A. 25 Lse (548)

19 AAQKPDV...GG.N..G.KL....V. 44 BlC (508)

1 MTNQ...NE.Q.WADN.H.Q.AA 23 LSa (46\%)

73 KGSENYA. . NQ.VRIA.D. . . RA. 98 ECO (42\%)

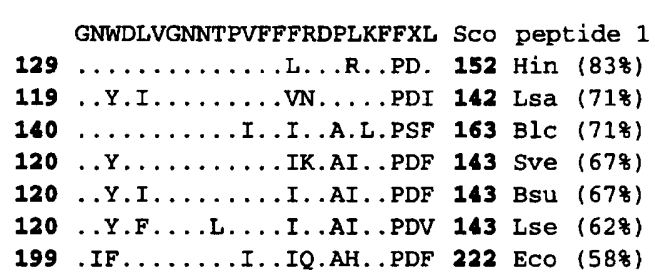

LNRNPDNYFADVEQNAFGRANVVPGRSFXPDRMLN SCO peptide $2 / 3$

306 ....E.F.........A.S.L...IGAS..... 340 Hin (698)

297 ....E.I.E...SI...HF...IGPS..K..Q 331 Sve (638)

297 .D...E...E.......GTL...IDVS..K..Q 331 Bsu (638)

307 ....V....E...L..D.S.MP..IEPS..K..Q 341 BlC (63\%)

$385 \ldots \ldots$....EN.....H.GHI...LD.TN.PL.Q $\$ 19$ ECO (60\%)

296 .DE..T.N.E.IQEL.........IEAS..KL.Q 330 LSa (518)

297 .........ET.SVG.N.GVL...MLPSE..L.Q 331 Lse (518)

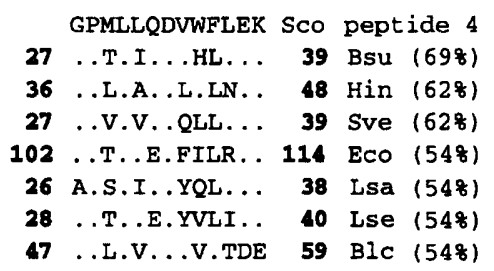

Fig. 3. Multiple alignment of the $\mathrm{S}$. coelicolor $\mathrm{N}$-terminal and peptide amino acid sequences with bovine liver catalase and other prokaryotic catalase sequences. All sequences are shown by the single-letter amino acid notation. The letter $X$ represents amino acid residues unidentified during the micro-sequencing. The organisms and/or sources of sequences are: $B \mid c$, bovine liver catalase (Schroeder et al., 1982); Bsu, B. subtilis (Bol \& Yasbin, 1991); Eco, E. coli K12 (von Ossowski et al., 1991); Hin, $H$. influenzae (Bishai et al., 1994); Lsa, Lactobacillus sake (Knauf et al., 1992); Lse, Listeria seeligeri (Haas et al., 1991); Sco, S. coelicolor (this study); Sve, S. venezuelae (S. Facey, K. H. Van Pee \& L. C. Vining, unpublished; accession no. X74791). The amino acid positions of the aligned regions of the catalases are numbered to indicate their position within the entire coding region. Dots represent identity with the $S$. coelicolor sequence. Bold lettering in the peptide $2 / 3$ sequence indicates where these two peptides overlap. The overall identity with the $S$. coelicolor sequence is indicated in parentheses and the organisms are listed in order of decreasing identity.

peroxidase is responsible for the formation of carbonhalogen bonds in the presence of peroxides as well as possessing catalase activity and very low peroxidase activity (Knoch et al., 1989).

The peptide sequences obtained also exhibited a high degree of similarity with other prokaryotic catalases (Fig. 3). Among the peptide sequences obtained, some residues involved in catalysis and haem-binding were found to be conserved (Fig. 3), namely Asn-8 of peptide 1 (catalysis), Phe-13 and Phe-21 of peptide 1 (distal side for haembinding), Pro-6, Asp-18 and Met-20 of peptide 3 (proximal side for haem-binding) (Fita \& Rossmann, 1985). 


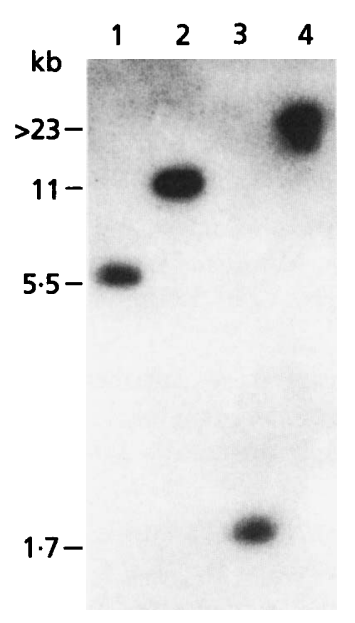

Fig. 4. Southern blot analysis of $S$. coelicolor genomic DNA digested with the restriction endonucleases Sstl (lane 1), BamHI (lane 2) and Sall (lane 3), or undigested (lane 4). The size of the single strongly hybridizing band for each lane is indicated. The filter was then stripped, re-probed with the internal oligonucleotide and the same hybridizing bands were identified.

S. coelicolor appears to possess a typical tetrameric catalase similar to those isolated from eukaryotic sources (Deisseroth \& Dounce, 1970; Saeh \& Kaplan, 1973; Jacob \& Orme-Johnson, 1979) and some bacteria (e.g. Jouve et al., 1983; Kim et al., 1994). This sequence information agrees with other data showing the catalases to be a well-conserved group of proteins (Okada et al., 1987; von Ossowski et al., 1991), although bacterial catalases do appear to be more heterogeneous in sequence than eukaryotic catalases (von Ossowski et al., 1993).

\section{Southern blot analysis}

Southern blot analysis using oligonucleotide probes designed against $\mathrm{N}$-terminal and internal peptide amino acid sequences derived from the $S$. coelicolor catalase yielded a single strongly hybridizing signal (Fig. 4), suggesting that a single catalase gene is present in $S$. coelicolor. This result is consistent with the purification data, which indicated that a single catalase activity was present.

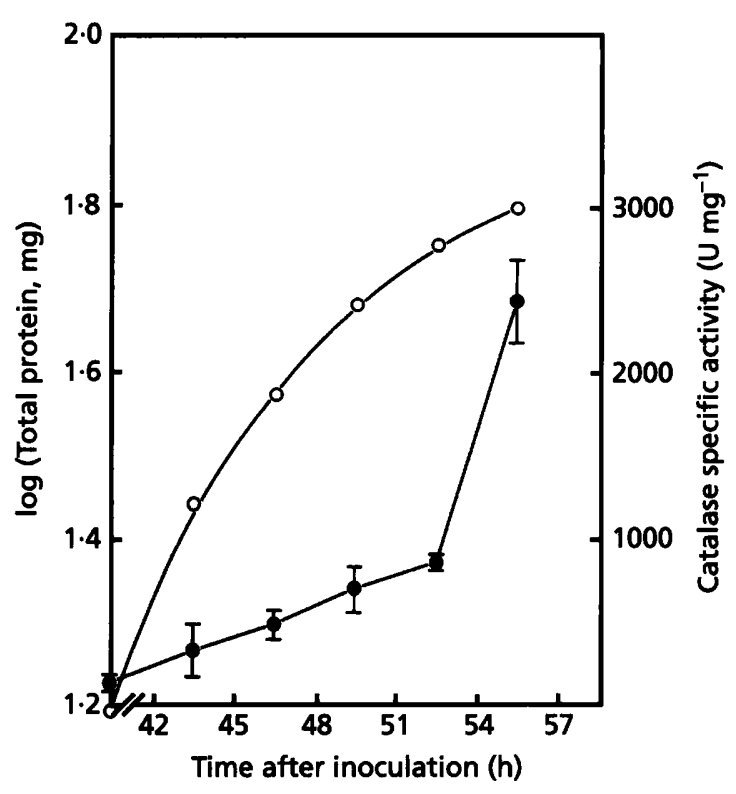

Fig. 5. Growth cycle and specific activity of catalase. $\bigcirc$. Total protein; O. catalase specific activity. Catalase activity was determined independently six times and the mean specific activity plotted with the SD shown by error bars. The time was measured from the start of the primary culture.

\section{Relationship between growth and catalase activity}

S. coelicolor was grown in minimal medium and samples were taken at different times throughout the growth of a batch culture and analysed for protein content and catalase activity. The results demonstrated that during growth catalase activity increased slowly in mid- to late-exponential phase and by almost threefold upon entry into stationary phase (Fig. 5). Similar elevated catalase activities were found in stationary-phase cells whenever such extracts were prepared.

The relatively high levels of catalase in stationary-phase cells made its purification straightforward. A simplified purification scheme using $\left(\mathrm{NH}_{4}\right)_{2} \mathrm{SO}_{4}$ fractionation and two Mono $\mathrm{Q}$ chromatography steps gave homogeneous enzyme of specific activity $125000 \mathrm{U} \mathrm{mg}^{-1}$ in $22 \%$ yield (Table 2). The purification factor was only 38 -fold compared with 250-fold from exponential-phase cells. The $\mathrm{N}$-terminal sequence, subunit $M_{\mathrm{r}}$, elution charac-

Table 2. Purification of $S$. coelicolor catalase from stationary-phase cells

\begin{tabular}{|lccccc|}
\hline Step & $\begin{array}{c}\text { Total } \\
\text { protein } \\
\text { (mg) }\end{array}$ & $\begin{array}{c}\text { Total } \\
\text { activity } \\
\text { (U) }\end{array}$ & $\begin{array}{c}\text { Specific } \\
\text { activity } \\
\left(\mathbf{U} \mathbf{~ m g}^{-1}\right)\end{array}$ & $\begin{array}{c}\text { Yield } \\
(\%)\end{array}$ & $\begin{array}{c}\text { Purification } \\
\text { (-fold) }\end{array}$ \\
\hline 1. Crude & 60 & 200000 & 3330 & 100 & 1 \\
2. $\left(\mathrm{NH}_{4}\right)_{2} \mathrm{SO}_{4}$ & 24 & 140000 & 5800 & 70 & $1 \cdot 6$ \\
3. Mono Q 1 & $2 \cdot 22$ & 62000 & 28000 & 42 & 8 \\
4. Mono Q 2 & $0 \cdot 35$ & 44400 & 125000 & 22 & 38 \\
\hline
\end{tabular}


teristics from Mono $Q$ and absorption spectrum were indistiguishable from those of enzyme purified from exponential-phase cells, confirming that the same form of catalase had been isolated in both cases.

Similar increases in catalase activity on entering stationary phase have been described in other systems (see for example Dowds et al., 1987). In E. coli, carbon-starved cells develop enhanced resistance to several forms of stress such as heat shock, oxidation, osmotic shock and starvation, with many proteins being induced (Matin, 1991). The induction of a large number of these proteins requires the putative sigma factor KatF (Lange \& Hengge-Aronis, 1991; McCann et al., 1991). One of these proteins, the KatE monofunctional catalase of $E$. coli is not inducible with $\mathrm{H}_{2} \mathrm{O}_{2}$, but is regulated in a growthphase-dependent manner (Schellhorn \& Hassan, 1988) by KatF (Loewen \& Triggs, 1984). In the Gram-positive bacterium $B$. subtilis, gene expression is required upon entry into the stationary phase to facilitate transition to the non-growing state, the initiation of the sporulation process and the production of extracellular enzymes and antibiotics (Sonenshein, 1989). Alternative sigma factors are responsible for the expression of these stationaryphase genes (Helmann \& Chamberlin, 1988), and an analogous system exists in Streptomyces (Westpheling et al., 1985; Buttner et al., 1988). It would be interesting to identify promoters upstream of the $S$. coelicolor catalase gene and determine how the catalase level is regulated. To this end, a clone containing part of the $S$. coelicolor A3(2) catalase gene has been obtained (G. E. Walker, unpublished).

\section{ACKNOWLEDGEMENTS}

We thank Drs Peter White and Richard Taylor for help with computer protein sequence analysis, Dr Ranjit Deka for advice on proteolysis and peptide blotting and Dr Jeff Keane (University of Leeds) for the clostripain peptide sequence. A major part of this work was supported by the SERC Initiative, Secondary Metabolism of Streptomyces, involving Glaxo and SmithKline Beecham.

\section{REFERENCES}

Altschul, S. F., Gish, N., Miller, E. W. \& Lipman, D. J. (1990). Basic local alignment search tool. $J$ Mol Biol 215, 403-410.

Beers, R. F. \& Sizer, I. W. (1952). A spectophotometric method for measuring the breakdown of hydrogen peroxide by catalase. $J$ Biol Chem 195, 133-140.

Binnie, C. (1990). The use of synthetic oligonucleotides as hybridization probes. Adv Gene Technol 1, 135-154.

Bishai, W. R., Smith, H. O. \& Barcak, G. J. (1994). A peroxide/ ascorbate-inducible catalase from Haemophilus influenzae is homologous to the Escherichia coli katE gene product. $J$ Bacteriol 176, 2914-2921.

Bol, D. K. \& Yasbin, R. E. (1991). The isolation, cloning and identification of a vegetative catalase gene from Bacillus subtilis. Gene 109, 31-37.

Bradford, M. M. (1976). A rapid and sensitive method for the quantitation of microgram quantities of protein utilizing the principle of protein-dye binding. Anal Biochem 72, 248-254.

Buttner, M. J., Smith, A. M. \& Bibb, M. J. (1988). At least three different RNA polymerase holoenzymes direct transcription of the agarase gene (dag A) of Streptomyces coelicolor A3(2). Cell 52, 599-607.

Chary, P. \& Natvig, D. O. (1989). Evidence for three differentially regulated catalase genes in Neurospora crassa: effects of oxidative stress, heat shock, and development. J Bacteriol 171, 2646-2652.

Chater, K. F. (1984). Morphological and physiological differentiation in Streptomyces. In Microbial Development, pp. 89-115. Edited by R. Losick \& L. Shapiro. Cold Spring Harbor, NY: Cold Spring Harbor Laboratory.

Christman, M. F., Morgan, R. W., Jacobson, F. S. \& Ames, B. N. (1985). Positive control of a regulon for defenses against oxidativestress and some heat-shock proteins in Salmonella typhimurium. Cell 41, 753-762.

Claiborne, A. \& Fridovich, I. (1979). Purification of the 0 -dianisidine peroxidase from Escherichia coli B. J Biol Chem 254, 4245-4252.

Claiborne, A., Malinowski, D. P. \& Fridovich, I. (1979). Purification and characterization of hydroperoxide II of Escherichia coli B. J Biol Chem 254, 11664-11668.

Cleveland, D. W., Fischer, S. G., Kirschner, M. W. \& Laemmli, U. K. (1977). Peptide mapping by limited proteolysis in sodium dodecyl sulfate and analysis by gel electrophoresis. $J$ Biol Chem 252, 1102-1106.

Deisseroth, A. \& Dounce, A. L. (1970). Catalase: physical and chemical properties, mechanism of catalysis and physiological role. Pbysiol Rev 50, 319-375.

Demain, A. L. (1989). Carbon source regulation of idiolite biosynthesis in actinomycetes. In Regulation of Secondary Metabolism in Actinomycetes, pp. 127-134. Edited by S. Shapiro. Cleveland, $\mathrm{OH}$ : CRC Press.

Devereux, J., Haeberli, P. \& Smithies, O. (1984). A comprehensive set of sequence analysis programs for the VAX. Nucleic Acids Res 12, 387-395.

Dowds, B. C. A., Murphy, P., McConnell, D. J. \& Devine, K. M. (1987). Relationship among oxidative stress, growth cycle, and sporulation in Bacillus subtilis. J Bacteriol 169, 5771-5775.

Fita, I. \& Rossman, M. G. (1985). The active center of catalase. J Mol Biol 185, 21-37.

Haas A., Brehm, K., Kreft, J. \& Goebel, W. (1991). Cloning, characterization, and expression in Escherichia coli of a gene encoding Listeria seeligeri catalase, a bacterial enzyme highly homologous to mammalian catalase. J Bacteriol 173, 5159-5167.

Helmann, J. D. \& Chamberlin, M. J. (1988). Structure and function of bacterial sigma factors. Annu Rev Biocbem 57, 839-872.

Hobbs, G., Frazer, C. M., Gardner, D. C. J., Cullum, J. A. \& Oliver, S. G. (1989). Dispersed growth of Streptomyces in liquid culture. Appl Microbiol Biotechnol 31, 272-277.

Hopwood, D. A., Bibb, M. J., Chater, K. F., Kieser, T., Bruton, C. J., Kieser, H. M., Lydiate, D. J., Smith, C. P., Ward, J. M. \& Schrempf, H. (1985). Genetic Manipulation of Streptomyces: a Laboratory Manual. Norwich: John Innes Foundation.

Jacob, G. S. \& Orme-Johnson, W. H. (1977). Catalase of Neurospora crassa: induction, purification and physical properties. Biochemistry 18, 2967-2975.

Jones, P., Pain, A. H. \& Suggett, A. (1970). Dissociation of catalase: a correlation between changes in sedimentation and spectroscopic properties accompanying dissociation of bacterial catalase in alkaline solution. Biocbem $J$ 118, 319-323.

Jouve, H. M., Tessier, S. \& Pelmont, J. (1983). Purification and properties of the Proteus mirabilis catalase. Can J Biochem Cell Biol 61, 8-14. 
Kim, H., Lee, J. S., Hah, Y. C. \& Roe, J. H. (1994). Characterization of the major catalase from Streptomyces coelicolor ATCC 10147. Microbiology 140, 3391-3397.

Knauf, H. J., Vogel, R. F. \& Hammes, W. P. (1992). Cloning, sequence, and phenotypic expression of kat $A$, which encodes catalase of Lactobacillus sake LTH677. Appl Environ Microbiol 46, 549-552.

Knoch, M., Van Pee, K. H., Vining, L. C. \& Lingens, F. (1989). Purification, properties and immunological detection of a bromoperoxidase-catalase from Streptomyces venezuelae and from a chloramphenicol-nonproducing mutant. J Gen Microbiol 135, 2493-2502.

Laemmli, U. K. (1970). Cleavage of structural proteins during the assembly of the head of bacteriophage T4. Nature 227, 680-685.

Lange, R. \& Hengge-Aronis, R. (1991). Identification of a central regulator of stationary phase gene expression in Escherichia coli. Mol Microbiol 5, 49-59.

Lee, J. S., Hah, Y. C. \& Roe, J. H. (1993). The induction of oxidative enzymes in Streptomyces coelicolor upon hydrogen peroxide treatment. J Gen Microbiol 139, 1013-1018.

Loewen, P. C. \& Switala, J. (1986). Purification and characterization of catalase HPII from Escherichia coli K12. J Biol Chem 64, 638-646. Loewen, P. C. \& Switala, J. (1987). Purification and characterization of catalase-1 from Bacillus subtilis. Biochem Cell Biol 65, 939-947.

Loewen, P. C. \& Switala, J. (1988). Purification and characterization of spore-specific catalase-2 from Bacillus subtilis. Biochem Cell Biol 66, $707-714$.

Loewen, P. C. \& Triggs, B. L. (1984). Genetic mapping of katF, a locus that with $k a t E$ affects the synthesis of a second catalase species in Escherichia coli. J Bacteriol 160, 668-675.

Loewen, P. C., Switala, J. \& Triggs-Raine, B. L. (1985). Catalases HPI and HPII in Escherichia coli ate induced independently. Arch Biochem Biophys 243, 144-149.

Loprasert, S., Negoro, S. \& Okada, H. (1989). Cloning, nucleotide sequence, and expression in Escherichia coli of the Bacillus stearothermophilus peroxidase gene (per A). J Bacteriol 171, 4871-4875.

McCann, M. P., Kidwell, J. P. \& Matin, A. (1991). The putative sigma factor KatF has a central role in development of starvationmediated general resistance in Eschericbia coli. J Bacteriol 173, 4188-4194.

McCord, J. M. \& Fridovich, I. (1988). Superoxide dismutase: the first twenty years (1968-1988). Free Radical Biol Med 5, 363-369.

McCord, J. M., Keele, R. B. \& Fridovich, I. (1971). An enzyme based theory of obligate anaerobiosis. Proc Natl Acad Sci USA 68, 1024-1027.

Matin, A. (1991). The molecular basis of carbon-starvation-induced general resistance in Escherichia coli. Mol Microbiol 5, 3-10.

Matsudaira, P. (1987). Sequence from picomole quantities of proteins electroblotted onto polyvinylidene difluotide membranes. J Biol Chem 262, 10035-10038.

Okada, H., Ueda, M., Sugaya, T., Atomi, H., Mozaffar, S., Hishida, T., Taranishi, Y., Okazaki, K., Takechi, T., Kamiryo, T. \& Tanaka, A. (1987). Catalase gene of the yeast Candida tropicalis. Eur J Biocbem 170, 105-110.

von Ossowski, I., Mulvey, M. I., Leco, P. A., Borys, A. \& Loewen, P. C. (1991). Nucleotide sequence of Escherichia coli katE, which encodes catalase HPII. J Bacteriol 173, 514-520.

von Ossowski, I., Hausner, G. \& Loewen, P. C. (1993). Molecular evolutionary analysis based on the amino acid sequence of catalase. $J$ Mol Evol 37, 71-76.

Saeh, T. C. \& Kaplan, J. G. (1973). Purification and properties of the catalase of bakers' yeast. J Biol Chem 248, 2889-2893.

Sambrook, J., Fritsch, E. F. \& Maniatis, T. (1989). Molecular Cloning: a Laboratory Manual, 2nd edn. Cold Spring Harbor, NY: Cold Spring Harbor Laboratory.

Schellhorn, H. E. \& Hassan, H. M (1988). Response of hydroperoxidase and superoxide dismutase deficient mutants of Escbericbia coli $\mathrm{K} 12$ to oxidative stress. Can J Microbiol 34, 1171-1176.

Schroeder, W. A., Shelton, J. R., Shelton, J. B., Robberson, B., Apell, G., Fang, R. S. \& Ventura, J. B. (1982). The complete amino acid sequence of bovine liver catalase and the partial sequence of bovine erythrocyte catalase. Arch Biochem Biophys 214, 397-421.

Sonenshein, A. L. (1989). Metabolic regulation of sporulation and other stationary-phase phenomena. In Regulation of Procaryotic Development: Structural and Functional Analysis of Bacterial Sporulation and Germination, pp. 109-130. Edited by I. Smith, R. A. Slepecky \& P. Setlow. Washington, DC: American Society for Microbiology.

Southern, E. M. (1975). Detection of specific sequences among DNA fragment separated by gel electrophoresis. I Mol Biol 98, 503-517.

Triggs-Raine, B. L., Doble, B. W., Mulvey, M. R., Sorby, P. A. \& Loewen, P. C. (1988). Nucleotide sequence of kat $G$, encoding catalase HPI of Escherichia coli. J Bacteriol 170, 4415-4419.

Westpheling, J. E., Raines, M. \& Losick, R. (1985). RNA polymerase heterogeneity in Streptomyces coelicolor. Nature 313, 22-27.

Wright, F. \& Bibb, M. J. (1992). Codon usage in the G+C-rich Streptomyces genome. Gene 113, 55-65.

Zhang, Y., Heym, B., Allen, B., Young, D. \& Cole, S. (1992). The catalase-peroxidase gene and isoniazid resistance of Mycobacterium tuberculosis. Nature 358, 591-593.

Received 30 December 1994; revised 14 February 1995; accepted 17 February 1995. 